\title{
创新创业教育线上线下混合式教学的实践与研究一以广东职业 技术学院为例
}

张坚炣

广东职业技术学院

DOI:10.32629/er.v3i4.2608

[摘 要] 信息技术的发展和社会对优质教育资源的迫切需求,为线上教育的发展提供了技术的支持和基础。新时代信息科技及人民生活水平的 发展加速了线上教育的发展, 同时带来了巨大挑战。作者对线上创新创业教育的发展现状、问题困境, 以及以广东职业技术学院为例所取得的线 上教育经验进行分析,并对“智能十创新创业教育”的发展提出一些思考。

[关键词] “智能十创新创业教育”; 线上线下混合式; 新时代教师

线上教育是利用网络信息平台和互联网技术打破时间和空间界限进 行教学内容传播和快速学习的形式, 丰富了教育教学的模式, 是我国高等 教育发展的重要方向和目标。创新创业教育旨在通过对学生进行创新创业 理论知识的教学, 让学生认识到创新的重要性, 掌握创新思维的训练方法, 了解创业的基本思路和方法论, 并能在遇到问题时提出解决方案, 是理论 与生活实践紧密结合学科。线上创新创业教育不仅仅是将互联网作为媒介, 而是将对互联网和创新创业教育两种资源的深度融合和平衡利用, 形成

“互联网+创新创业教育” 生态新模式。

\section{1 “互联网+创新创业教育” 的必然趋势}

1. 1 国家政策支持与引导

根据《教育信息化十年发展规划 (2011-2020年)》、《国务院办公厅关 于深化高等学校创新创业教育改革的实施意见》、《国务院关于强化实施创 新驱动发展战略进一步推进大众创业万众创新深入发展的意见》等文件精 神, 明确了 “互联网+” 教育与创新创业教育信息化的发展方向。刘延东副 总理在第二次全国教育信息化工作电视电话会议时强调, “要大力推进信 息技术与教育教学、创新创业的融合发展, 促进教育公平, 提高教育质量, 为培养现代化建设所需高素质人才提供有力支撑。” 教育部全力推进 “互 联网+”创新创业教育进程, 引导高校开展课程体系、教学方法、教学方式、 教师能力、管理制度等方面的综合改革, 进一步深化创新创业教育改革, 加快培养创新创业人才。中国国际 “互联网+” 大学生创新创业大赛旨在 以赛促教, 以赛促学, 探索素质教育新途径, 培养创新创业生力军。从 2015 年举办至今, 累计有 947 万名大学生、 230 万个大学生团队参赛, 是创新创业 教育重要的实践平台, 是人才培养的重要载体。

1. 2 信息技术的发展及社会对优质教育资源的需求

随着 $5 \mathrm{G}$ 通讯技术应用的加速推进, 网络高速公路畅通无阻, 人们对教 育越来越重视, 线上教育迅速普及。在线课程成为优化教育资源, 提升高等 教育教学质量和国民科学素养的主要抓手。国内外近些年不断涌现的 “翻 转课堂” (F1ipped Class-room)、“慕课” (MOOCs)、微课等依托信息技术 实施网络视频授课的教学模式。教育部日前表示, 截至目前, 共有12500门 慕课上线, 超过 2 亿人次学习者, 我国慕课的数量和应用规模位居世界第一, 并成为提高教育质量、推进教育公平的重要战略举措。依据国家计划, 到 2020年我国将建设两个 “一万门” 精品课程, 带动上万门的慕课开发。

\section{3大学生的时代特征}

大学生具有较强的信息技术应用和适应能力, 网络是新媒体时代大学 生活动的主要阵地, 很大程度改变了大学生学习方式、生活方式、互动方 式。互联网为大学生创新创业教育提供了新的传播工具、新的交流工具、
新的思维方式。互联网可以使创新创业教育者更新已有的知识体系、教育 方式, 为创新创业教育者提供新载体, 提高创新创业教育效率。新时代大学 生具有独特的思维方式, 线上教育能拉近教师与大学生之间的距离, 消解 了创新创业教育工作者的 “知识权威”, 促进教学相长。

\section{2 “互联网+创新创业教育” 的发展困境}

2.1 “互联网+创新创业教育” 平台分散, 资源质量良莠不齐

我国 “互联网+创新创业教育” 仍然处于发展的初级阶段。线上创新 创业教育课程资源多样、零散、不成熟、不系统, 质量和水平参差不齐; 缺乏较为完善的教学质量评估体系, 线上教育质量无法得到保证, 学生学 习成果得不到很好的检验的结果。创新创业教育与专业教育脱节, 没有充 分考虑学生的专业背景, 因材施教, 忽略了创新创业教育与专业教育的内 在联系, 变成一种技巧或技能教育, 难以实现创新创业教育的预期目标。

\section{2 “互联网+创新创业教育” 师资队伍素质参差不齐}

创新创业教育师资力量参差不齐, 从教学手段、教学内容上都沿袭着 较为传统的理论式教学模式。线上线下混合式创新创业教育对教师的能力 提出了更高的要求, 不仅需要具备洣博的专业知识和广博的其他学科知 识、深厚的教育学心理学知识、精通互联网+背景下的现代教育理论、具 有娴熟的信息技术应用知识等综合性素养, 而且需要担当各种角色以及落 实相应的教学实践等。撒奇等学者采用德尔斐法最终确定了线上教育教师 的11种角色和素养范畴, 即 “教师、技术专家、教学设计者、管理者这4 种主要角色, 和学习资源管理者、辅导站工作者、编辑、辅助人员、技术 员、评价专家、图形设计者7种辅助角色”。现阶段创新创业师资队伍综合 素质还没有达到要求。

表1 撒奇等人定义的在线教育教师 “教学” 角色和能力

\begin{tabular}{|l|l|l|}
\hline 角色 & 职责 & 能力 \\
\hline \multirow{6}{*}{ 教师 } & 内容表述清晰、组织严密 & 策划能力 \\
& 课前计划与准备 & 教学设计 \\
& 掌握专业知识 & 专业知识 \\
& 设立学习目标与预期效果 & 调控行为的能力 \\
& 人际交流能力 \\
& 瑷教学 & 反馈能力 \\
& 向学习者提供及时反馈 & 表达能力 \\
& 呈现信息 & 英语专业能力基本技术知识 \\
& 灵活运用技术 & 基本技术知识 \\
& 指导并评估学生学习成绩 & 评价能力 \\
& 与技术人员及教辅人员合作 & 教学技巧 \\
& 创设多种学习活动 & 组织小组学习的能力 \\
& 组织交互性讨论 & 需求评估能力 \\
& 掌握学习者的学习风格及学习需求 & 提问能力 \\
& 鼓励同伴学习 & 学习风格与学习理论知识 \\
& 为学生提供咨询指导 & 指导与咨询水平 \\
\hline & 参与教学设计 & \\
\hline
\end{tabular}




\section{3 线上教育过程缺乏有效监管}

互联网对大学生的学习、生活、娱乐有深远的影响。线上教育制度及 模式受地域、院校、专业等因素影响无法统一,创新创业实践无法实现。 部分学生缺乏自制力, 在线上学习会出现投机取巧、态度不端正等现象。 因为缺乏有效的监督管理, 会使学生的内在激励机制产生不良影响, 对线 上教育内容学习态度不积极, 导致线上教育教学的效果低下。

\section{3 “互联网+创新创业教育” 的实施与研究}

3. 1 开发 “互联网+创新创业教育” 校本课程, 建设一批具有学校专业 特色的线上教学资源

以我校纺织专业创新创业教育课程为例。线上线下混合式创新创业教 育课程立足于纺织专业特色文化, 以提升大学生创新创业能力为核心, 将 “纺织面料检测技能大赛”、“纺织面料分析技能大赛”、“全国职业院校学 生纺织面料检测技能大赛”、“创青春 - 挑战杯”、“互联网+创新创业大赛” 等技术技能大赛作为创新创业教学案例及实践项目，与创新创业教育相融 合。构建立足专业, 分类分层、深度融合、协同递进的创新创业教育体系。 引导对纺织服装行业产业创新应用、技术开发、前沿科技等的思考, 去发 现纺织服装行业存在的问题与机遇、寻找方法、创造条件、解决实际问题, 促进创新创业教育成果落地, 激发学生学习创新创业的热情。

3.2搭建 “智能+教育” 新平台, 加强学习过程监管, 增强学生的参与和 体验

线上线下混合式创新创业教育依托创新创业全过程实训平台, 以学生 为主体, 教师为主导实施混合式教学, 以成果为导向, 以创新创业实践流程 为主线, 以信息化技术为手段, 把创业课程标准化、可复制化, 实现创新创 业项目从课堂孵出, 创新创业项目在课堂迭代, 解决老师们全校通识类创 业课程授课难问题, 增强学生的参与和体验, 促进知识的吸收和内化。将课 程设计为 “新道云 $V$ 创平台实训 (线上预习与课后作业、实训) +腾讯课堂直 播 (线上学习)+腾讯会议指导 (线上指导项目) 的网课方式”。课程共 32 学时, 其中线上教学部分为 16 个学时, 学生需要完成 8 个视频课学习; 线下授课为 16 学时, 包括 8 个课时的集中授课和 8 个课时的实训项目指导。课程遵循创 新创业活动过程的内在规律, 先理论后实践原则, 理论课程与实践课程搭 配组合, 理论与实践互相促进。把握课前、课中、课后三过程。课前, 通过
前期录制微课讲理论, 让学生掌握重要知识点; 课中, 进行直播交流, 答疑 解惑、教方法、指方向; 课后, 完成实训平台实训任务, 重实践理解, 促使 创新创业理论与创新创业实践相融合。同时为创新创业精英班的教育提供 了信息技术手段支持, 从项目培养、孵化到投资创造平台, 助力项目的打磨 及迭代, 更好地服务跟创造优质项目。

3. 3加强师资队伍建设, 提升 “互联网+创新创业教育” 教师综合素质 线上线下混合教育模式要求教师承担课程和教学设计者、组织者、技 术支持者、评估者与学习顾问、教学交互促进者等角色任务, 师资力量起 到举足轻重的作用。以学校纺织专业创新创业教育为例, 学校在纺织服装 类专业上, 积累了丰厚的校友资源, 校友在纺织服装产业的创新发展中起 到了中流砥柱的作用, 要充分发挥校友资源, 凝聚创新创业教育资源, 聘请 优秀校友成为校外创新创业导师引导学生对行业产业创新应用、技术开 发、前沿科技等的思考及丰富的行业产业资源。同时, 要加强校内外师资 队伍培训力度, 组织专家针对 “线上教学设计基本原理、线上教育教学法、 线上教育评价等” 进行培训; 组织开展教研活动, 促进教师之间交流经验; 引导线上授课教师加强自我反思, 总结提升。

\section{4 结语}

在新时代 “互联网+教育” 的背景下, 面对线上创新创业教育建设和管 理中的困难, 我们应该提高认识、强化责任担当, 改变思维, 从实际出发, 遵循教育教学规律, 不断提升信息技术教育应用水平, 结合学生专业特点 和教学要求, 积极探索线上创新创业教育, 完善考核体系, 不断探索 “互联 网+创新创业教育” 新模式, 提高创新创业人才培养质量。

\section{[参考文献]}

[1]汪鹏.020教育模式未来教师探究 [J].上海师范大学,2017,(2):32.

[2]董宝莹,郡星源。“互联网+”背景下高校线上教育模式探讨一以 南京农业大学为例[J].文化创新比较研究,2019,3(29):172-173.

[3]戴宁, 曹辉. “互联网+教育”: 颠覆、应对与重构 [J].教育与教学研 究,2016,30(07):16-20.

\section{作者简介：}

张坚炿(1992--), 男, 汉族, 广东省佛山人, 本科, 研究方向: 大学生职 业规划与创新创业教育。 